旋回クレーンの簡易ロバスト制御*

高 木 章 二*1, 内 山 直 樹*1

\title{
Simple Robust Control of Rotary Cranes
}

\author{
Shoji TAKAGI and Naoki UCHIYAMA*2 \\ ${ }^{* 2}$ Department of Mechanical Engineering, Toyohashi University of Technology, \\ 1-1 Hibarigaoka, Tempaku-cho, Toyohashi-shi, Aichi, 441-8580 Japan
}

\begin{abstract}
This paper deals with a control method of rotary cranes with rotating and boom-hoisting operations. The control systems should have robustness with respect to rope length, mass of load and frictional disturbances, which are variant parameters in the rotating and the boom-hoisting motions. Firstly we derive a simple linear model of the crane dynamics by using a disturbance observer. The model has robustness with respect to the mass of load and the frictional disturbances. Although dynamics of the rotary crane are described by a double-input quadruple-output nonlinear system, the derived linear dynamics are two single-input double-output systems, so that we can easily design the robust control system with respect to the rope length. In the control system, by using nominal natural frequencies of rope-load vibration system, desired closed-loop poles are easily assigned without trial and error. We further propose a method of adding an integrator to the controller for reducing positional errors of the crane. The effectiveness of the proposed method is experimentally confirmed by comparisons with conventional controllers.
\end{abstract}

Key Words: Motion Control, Vibration Control, Mechatronics and Robotics, Rotary Crane, Pole Placement Control

\section{1.はじめに}

旋回クレーンは建設現場やトラックの荷台等におい て広く利用されており，またその操作には熟練を要す るため, 荷振れの振動制御に関する研究がこれまでに 多く行なわれている ${ }^{(1)}(9)$. 旋回クレーンの基本動作 はつぎのとおりである.

（a1）ロープ長を変化させることによる吊り荷の上昇, 下降.

(a2) ブームの起伏と旋回動作.

動作 (a1) は荷振れの原因となる動作ではないため, 作 業者によって容易に行なうことができると考えられる. 動作 (a2) の荷振れ制御系を構成したとき，考虑される ベき変動パラメータとして, ロープ長, 吊り荷の質量, 各関節駆動部の摩擦が挙げられ，制御系はこれらに関 してロバスト性を有することがのぞましい，特にロー プ長に関してロバスト性を有するように制御系を構築 することができれば，動作 (a1) は作業者によって容 易に行なうことができることから，ロープ長を計測す るセンサを必要とすることなくクレーンを制御できる

\footnotetext{
* 原稿受付 2003 年 4 月 7 日。

*1 正員, 豊橋技術科学大学機械システム工学系( 441-8580 豊橋市天伯町雲雀ヶ丘 1-1)。

E-mail : uchiyama@mech.tut.ac.jp
}

ことになる.ロープ長は荷振れ特性であるロープー吊 り荷系の固有周波数を定めることから、この制御系は 固有周波数に関してロバスト性を有することになる. 動作 (a2) の制御に関する既存の研究はオンライン で荷振れ角あるいはそれに準ずる情報を利用する方法 (2)(4)(5)(6)(8) とそうでないもの ${ }^{(1)(3)(7)(9)}$ に大別できる. オンラインで荷振れ角を利用しない方法では屋外作業 において風などの外乱により所望の制御性能が得られ ない可能性がある. 荷振れ角あるいはそれに準ずる情 報を利用する方法としては, 目標状態近傍まではオー プンループ制御を行い, 目標状態近傍においてフィー ドバック制御に切り替える方法 ${ }^{(2)}$, 直接最適制御によ る方法 ${ }^{(4)}$, ファジィ制御による方法 ${ }^{(5)}$, タワークレー ンを対象としタワー部と吊り荷の振動の連成を利用す る方法 ${ }^{(6)}$, ロバスト性を有する適応制御による方法 ${ }^{\left({ }^{(}\right)}$ 等があるが，いずれの研究においてもロープ長に関す るロバスト性を解析的に検討したものはない.

本研究ではブームがその目標状態近傍まで既存の適 当な方法によって制御されることを前提とし, 目標状 態近傍において吊り荷の残留振動抑制とブームの最終 的な位置決めを行なうロープ長, 吊り荷の質量, 関節 駆動部の摩擦等に関してロバストなフィードバック制 御則の提案を目的とする.この際, クレーンの目標状 
態近傍における線形化モデルに基づいて制御系を構築 することとする.

まずはじめに文献 (1) で示されているブームの旋回 動作のみを考慮した動特性モデルを基に, ブームの起 伏動作を考慮した簡単な線形化モデルを導出する．こ の線形化モデルは外乱オブザーバ(10)を利用することに より, 吊り荷の質量, 関節駆動部の摩擦等に関してロ バスト性を有する．つぎに線形化モデルに基づきロー プ長に関してロバストな制御系を構成する.制御則と しては極配置法を用いているが，ロープー吊り荷系の 固有周波数の公称值を利用した極配置を行うことによ りロープ長に関してロバスト安定な制御系が構築でき ることを示す．さらにブームの位置決め誤差を低减す るために積分器を付加したロバスト性能を有する制御 系の設計法も提案する. 最後に実験結果との比較によ り本方法の有効性を検証する.

\section{2. 旋回クレーンの䡃特性モデリング}

旋回クレーンの動特性は複雑な非線形性を有し多く の数式モデルが提案されているが(1)(2)(4)(5)(6)(8)(9), 制 御系設計のためには簡潔なモデルがのぞましいことか ら本研究では文献 (1) のモデルを参考にした. ただし 文献 (1)では, 吊り荷の残留振動が生じないように旋回 動作を行なうオープンループ制御系の設計を目的とし ているため, 起伏動作の動特性は含まれておらず, こ れを考慮する必要がある. 文献 (1)(3)(7)(9) ではロー プ張力のブームへの影響を陽に考虑せずにモデル化が 行なわれているが, 起伏動作に対するロープ張力の影 響は大きいことも多い.ロープ張力は吊り荷の質量に 大きく依存するが，一般に吊り荷の質量は未知であり， これに対処する必要がある. また数式モデルを線形化 したときに起伏と旋回動作に関する動特性が非干涉化 されるように, 文献 (1) とは異なる座標系により荷振 れを表現する.

図 1 に旋回クレーンの概略図とその状態を記述する ためのパラメータを示す. 記号の意味はつぎのとおり である. $x, y, z$ :吊り荷の 3 次元位置, $\theta:$ :ブー先端 を通る鉛直軸からの荷振れ角, $\theta_{1}, \theta_{2}:$ ブームに沿う方 向ならびにその垂直方向の荷振れ角, $\theta_{3}, \theta_{4}:$ :゙ームの 起伏角度ならびに旋回角度, $m$ :吊り荷の質量, $l$ :ロー プ長, $l_{b}:$ ブーム長, $f:$ ロープ張力.

本研究のモデリングにおいては過去の多くの研究と 同様に以下を仮定する.

(b1) ロープの張力による伸びと質量は無視できる.

（b2）吊り荷は質点とみなし，ロープのねじれは無視で きる.

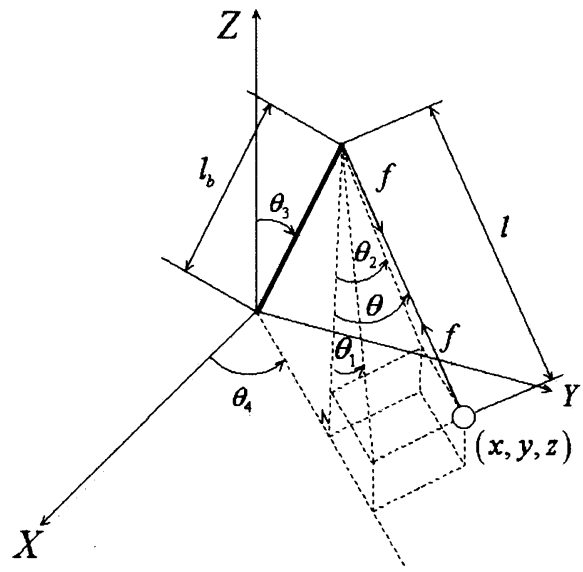

Fig. 1 Schematic model of rotary crane

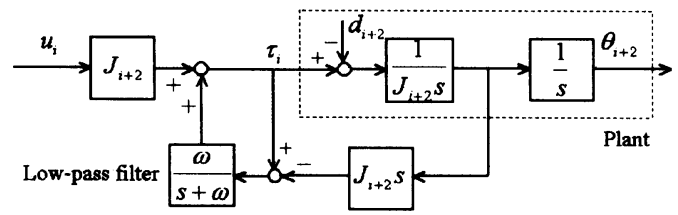

Fig. 2 Control system with disturbance observer

（b3）吊り荷ーロープ系の振動は 1 次モードのみを考虑 する.

(b4) 荷振れは十分小さく図 1 において $\sin \theta_{i} \simeq$ $\theta_{i}, \cos \theta_{i} \simeq 1(i=1,2) \sin \theta \simeq \theta, \cos \theta \simeq 1$ が成り立つ.

ブームの起伏と旋回に関する動特性はつぎのように 表現できる.

$$
J_{i+2} \ddot{\theta}_{i+2}+d_{i+2}=\tau_{i}, i=1,2 .
$$

ここで $J_{i+2}$ は慣性公称值, $\tau_{i}$ はブームの起伏および 旋回関節を駆動するトルク入力であり, $d_{i+2}$ は $J_{i+2}$ に含まれない慣性, 遠心力, コリオリカ, 重力, 摩擦 力等の影響をまとめたものである. 式 (1) を対象に図 2 の外乱オブザーバ(10) に基づく制御系を構成する. た だし $s, u_{i}, \omega$ はそれぞれ微分演算子, 新たな制御入力, ローパスフィルタのカットオフ角周波数である.これ により低周波数域において近似的に以下の動特性が得 られる.

$$
\ddot{\theta}_{i+2}=u_{i}, i=1,2 .
$$

仮定 (b4) より吊り荷の運動に関するつぎの式を得る.

$$
\begin{aligned}
& m \ddot{x}=-f\left(\theta_{1} \cos \theta_{4}-\theta_{2} \sin \theta_{4}\right), \\
& m \ddot{y}=-f\left(\theta_{1} \sin \theta_{4}+\theta_{2} \cos \theta_{4}\right), \\
& m \ddot{z}=-m g+f .
\end{aligned}
$$


一方, 吊り荷の位置はつぎのように表される.

$$
\begin{aligned}
& x=l_{b} \sin \theta_{3} \cos \theta_{4}+l\left(\theta_{1} \cos \theta_{4}-\theta_{2} \sin \theta_{4}\right),(6) \\
& y=l_{b} \sin \theta_{3} \sin \theta_{4}+l\left(\theta_{1} \sin \theta_{4}+\theta_{2} \cos \theta_{4}\right),(7) \\
& z=l_{b} \cos \theta_{3}-l .
\end{aligned}
$$

式 (3) (8) よりつぎの運動方程式を得る.

$$
\begin{gathered}
\ddot{x}=-\frac{g+\ddot{z}}{l}\left(x-l_{b} \sin \dot{\theta_{3}} \cos \theta_{4}\right), \\
\ddot{y}=-\frac{g+\ddot{z}}{l}\left(y-l_{b} \sin \theta_{3} \sin \theta_{4}\right) .
\end{gathered}
$$

つぎにクレーンの目標状態近傍における線形化モデ ルを導出する. まずつぎのようにクレーンの状態量と その微分值および制御入力を, 目標状態における值と そこからの偏差量に置き換える.

$$
\begin{array}{r}
\theta_{j}=\theta_{j f}+x_{j}, \dot{\theta}_{j}=\dot{\theta}_{j f}+x_{j+4}, \\
\ddot{\theta}_{j}=\ddot{\theta}_{j f}+\dot{x}_{j+4}, j=1, \cdots, 4, \\
u_{i}=u_{i f}+w_{i}, i=1,2 .
\end{array}
$$

ただし, $\theta_{j f}, \dot{\theta}_{j f}, \ddot{\theta}_{j f}, u_{i f}$ は目標状態における值（定 数) であり, $x_{j}, \dot{x}_{j}, w_{i}$ は偏差量である. 式(6),(7),(8) を時間に関して 2 階微分したものを式(9),(10)に代入 し, クレーンの目標状態 $\theta_{3 f} ; \theta_{4 f} ; \theta_{j f}=0 ; \dot{\theta}_{j f}=$ $0 ; \ddot{\theta}_{j f}=0 ; u_{i f}=0(i=1,2, j=1, \cdots, 4)$ の近傍で $x_{j}, \dot{x}_{j}(j=1, \cdots, 8)$ が微小であると仮定して線形化 するとつぎの非干渉な 2 つ状態方程式が得られる.

$$
\begin{aligned}
& \dot{\boldsymbol{x}_{i}}=\boldsymbol{A}_{i} \boldsymbol{x}_{i}+\boldsymbol{b}_{i} w_{i}, i=1,2, \\
& x_{i}=\left[\begin{array}{llll}
x_{i} & x_{i+2} & x_{i+4} & x_{i+6}
\end{array}\right]^{T},
\end{aligned}
$$

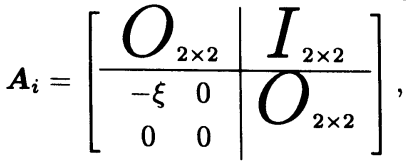

$$
\begin{aligned}
& \boldsymbol{b}_{i}=\left[\begin{array}{llll}
0 & 0 & \alpha_{i} & 1
\end{array}\right]^{T}, \\
& \xi=\frac{g}{l}, \alpha_{1}=-\frac{l_{b} \cos \theta_{3 f}}{l}, \alpha_{2}=-\frac{l_{b} \sin \theta_{3 f}}{l} .
\end{aligned}
$$

ただし, $O_{2 \times 2}, I_{2 \times 2}$ はそれぞれ 2 行 2 列の零行列, 単 位行列を意味する. 式(12)に対する可制御性行列を構 成すると, 可制御となるのは, $\sin \theta_{3 f} \neq 0, \cos \theta_{3 f} \neq 0$ のときに限ることがわかる. よって, 以下では $\theta_{3 f} \neq$ $n \pi / 2,(n=0,1,2, \ldots)$ を仮定する.

式 (12) より， $\theta_{1}$ と $\theta_{3}$ を $w_{1}$ により， $\theta_{2}$ と $\theta_{4}$ を $w_{2}$ により，それぞれ独立に制御できることがわかる．ま た, 式 (12) の 2 つの状態方程式は同じ形を有してい るので，それぞれの制御系を統一的に設計できる.

\section{3. 制 御 方 法}

\section{1 制御系設計に関する仮定制御系の構筑に} 際してつぎの事項を仮定する.

(c1) 状態量 $\theta_{i}(i=1, \cdots, 4), \dot{\theta}_{3}, \dot{\theta}_{4}$ が計測できる.

(c2) 何らかの方法によりブームは目標状態近傍へ移動 されている。

第 1 章で述べた動作 (a2) の制御系において変動す るパラメータのうち, 吊り荷の質量と関節駆動部の摩 擦の影響については図 2 の外乱オブザーバにより補償 されるため,ここでは吊り荷の残留振動抑制とブーム の位置決めを目的としたロープ長に関してロバスト性 を有する制御系の構築について述べる.

3.2 ロープ長に関するロバスト安定化＼cjkstart式(12) の線形系につぎの状態フィードバック制御を応用する.

$$
w_{i}=-\boldsymbol{k}_{i}^{T} \boldsymbol{x}_{i}, \boldsymbol{k}_{i}^{T}=\left[\begin{array}{lll}
k_{i 0} & \ldots & k_{i 3}
\end{array}\right], i=1,2 .
$$

この制御では $\boldsymbol{x}_{\boldsymbol{i}} \rightarrow \mathbf{0}$ を目的としており，この目的 が達成されたとき $\theta_{3}, \theta_{4}$ は目標角度に収束し, かつ吊 り荷の振動は抑制される. 式 (13) では荷振れ角速度 $\dot{\theta}_{i}(i=1,2)$ が利用されているが，これは後述する方 法により不要となる.

式 (12) を可制御正準形式に変換する変換行列

$$
\boldsymbol{T}_{i}=\left[\begin{array}{cccc}
0 & 0 & \alpha_{i} & 0 \\
\xi & 0 & 1 & 0 \\
0 & 0 & 0 & \alpha_{i} \\
0 & \xi & 0 & 1
\end{array}\right]
$$

を用いて, 可制御正準形式に対するフィードバック係 数ベクトル

$$
\boldsymbol{k}_{t i}^{T}=\left[\begin{array}{lll}
k_{t i 0} & \ldots & k_{t i 3}
\end{array}\right]=\boldsymbol{k}_{i}^{T} \boldsymbol{T}_{i}
$$

を定義すると, 制御系の特性多項式 $P_{i}(s)$ はつぎのよ うに与えられる.

$$
\begin{aligned}
& P_{i}(s)=\left|s I_{4 \times 4}-A_{i}+b_{i} k_{i}^{T}\right|= \\
& s^{4}+k_{t i 3} s^{3}+\left(k_{t i 2}+\xi\right) s^{2}+k_{t i 1} s+k_{t i 0} .
\end{aligned}
$$

一方, 制御系の望ましい特性多項式 $P_{d}(s)$ をつぎの ように指定する.

$$
P_{d}(s)=\prod_{j=1}^{2}\left(s^{2}+c_{2 j-1} s+c_{2 j}\right) .
$$

ただし, $c_{j}(j=1, \ldots, 4)$ は適当な倸数であり，これ らが全て正であるときに限り, 式 (17) は安定多項式 となる. 以下では, $c_{j}>0$ を仮定する.

式(16) と式 (17) の各倸数を比較し, 式 (15) を考慮 すると, 望ましい特性多項式を実現するためのフィー 
ドバック係数行列がつぎのように得られる. ただし, $\xi, \alpha_{i}$ に含まれる $l$ の值は未知と仮定しているため, 代 わりにその公称值 $\hat{l}$ を用いた $\hat{\xi}, \hat{\alpha}$ を利用する. また $\hat{\xi}>0$ を仮定する.

$$
\begin{aligned}
k_{i 3} & =\frac{c_{1} c_{4}+c_{2} c_{3}}{\hat{\xi}}, \\
k_{i 2} & =\frac{c_{1}+c_{3}-k_{i 3}}{\hat{\alpha}_{i}}, \\
k_{i 1} & =\frac{c_{2} c_{4}}{\hat{\xi}}, \\
k_{i 0} & =\frac{c_{1} c_{3}+c_{2}+c_{4}-\hat{\xi}-k_{i 1}}{\hat{\alpha}_{i}} .
\end{aligned}
$$

式 (15), (16), (18) (21) より, パラメータ見積り 誤差を考慮した閉ループ系の特性多項式はつぎのよう に表される。

$$
\begin{aligned}
P(s) & =s^{4}+a_{3} s^{3}+a_{2} s^{2}+a_{1} s+a_{0}, \\
a_{0} & =c_{2} c_{4} \frac{\xi}{\hat{\xi}}, a_{1}=\left(c_{1} c_{4}+c_{2} c_{3}\right) \frac{\xi}{\hat{\xi}} \\
a_{2} & =\left(c_{1} c_{3}+c_{2}+c_{4}\right) \frac{\xi}{\hat{\xi}}+\frac{c_{2} c_{4}}{\hat{\xi}}\left(1-\frac{\xi}{\hat{\xi}}\right), \\
a_{3} & =\left(c_{1}+c_{3}\right) \frac{\xi}{\hat{\xi}}+\frac{\left(c_{1} c_{4}+c_{2} c_{3}\right)}{\hat{\xi}}\left(1-\frac{\xi}{\hat{\xi}}\right) .
\end{aligned}
$$

式(12)における $i=1,2$ の両制御対象に対して制御系 の特性多項式は同じ形になるため, 起伏, 旋回動作共 に同一の制御則によって制御目的を達成することがで きる. また式(22) は式(12)のブーム長さ $l_{b}$ および起 伏角度の最終目標值 $\theta_{3 f}$ に依存しないので, 安定性は ロープー吊り荷系の固有振動数とその公称值および望 ましい特性多項式の係数のみによって決定される.

Lienard と Chipart の安定判別法 ${ }^{(12)}$ によれば, 式 (22) が安定多項式であるための必要十分条件は, つぎ のとおりである.

$$
\begin{aligned}
& a_{i}>0, i=0, \ldots, 3, \\
& a_{1}\left(a_{2} a_{3}-a_{1}\right)-a_{0} a_{3}^{2}>0 .
\end{aligned}
$$

本研究では $\hat{\xi}>0$ を仮定していることから，つぎの ように $c_{2}, c_{4}$ を指定することを提案する.

$$
c_{2}=c_{4}=\hat{\xi} \text {. }
$$

式 (25)によ゚り, 式 (23) が満たされることが容易に わかる. また式(18),(19),(25) より $k_{2}=0$ となり荷振 れ角速度 $\dot{\theta}_{i}(i=1,2)$ は不必要となる.

式 (24) の左辺は式 (25) を考虑することによりつぎ のように変形できる.

$$
a_{1}\left(a_{2} a_{3}-a_{1}\right)-a_{0} a_{3}^{2}=\left(c_{1}+c_{3}\right)^{2} c_{1} c_{3} \xi \frac{\hat{l}}{l}>0 .
$$

すなわち式 (24) が成立することが示された.

すなわち，式 (25) のようにロープー吊り荷系の固 有振動数の公称值を利用して制御系の望ましい特性多 項式の一部の係数を指定することにより，ロープ長の 変化に対する制御系のロバスト安定性が保証される.

3.3 口バスト制御性能定置制御においては, 代表極（虚軸に最も近い極）が図 3(a) の斜線部分に 存在することが望ましいといわれている(13).ただし 極の配置は実軸に関して対象のため虚部が負の領域は 省略している.

本研究では式 (17) の残りの係数 $c_{1}, c_{3}$ について,

$$
c_{1}=c_{3}=2 \sqrt{\hat{\xi}}
$$

と指定することにより， $\xi=\hat{\xi}$ となったときの制御系 の極を実軸上に配置することを提案する. このことに より $\xi$ 見積り誤差がある場合にも制御系の極が図 3(a) の斜線部分にある可能性が高くなる.

この方法の妥当性を検証するために， $\xi$ の見積り誤 差があるときの極（式 (22) の特性多項式の零点）の 位置を調べた．図3(b) は

$$
\xi=\hat{\xi}(1+\delta) \text { or } \hat{l}=l(1+\delta), \delta>-1
$$

とおき, $\hat{l}=0.1[\mathrm{~m}]$ として見積り誤差 $\delta$ を $-0.7 \sim$ 11.1 の範囲で変化させたときの根軌跡である. 図中の $\delta+, \delta$-はそれぞれ $\delta$ のきさを正方向, 負方向に増加 させたときの軌跡である. $\delta=-0.8$ あるいは $\delta=11.2$ のとき, 極の位置は図 3(a) の斜線部分の外側となっ

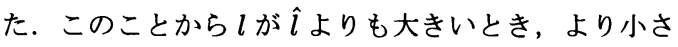
い見積り誤差 $|\delta|$ によって制御性能が劣化することが わかる。

図 3(c) は $\hat{l}=10.1[\mathrm{~m}]$ としたときの, 図3(b) と同様 の $\delta$ の範囲に対する根軌跡である. 各軸のスケールは 図 3(b) と異なっており, 根軌跡は図 3(b) のものを縮 小した形となっている. この場合も図 3(b) の場合と 同じく $\delta=-0.8$ あるいは $\delta=11.2$ のとき, 極の位置 は図 3(a)の斜線部分の外側となった.

図 3(d) は $\hat{l}$ を $0.1[\mathrm{~m}] \sim 10.1[\mathrm{~m}]$ の範囲で $0.5[\mathrm{~m}]$ ず つ変化させ, その各々の $\hat{l} に$ 対して $\delta を-0.7 \sim 11.1$ の範囲で変化させたときの全ての極の位置である. 全 ての極は図 3(a) の斜線部分に存在している. 図中の $\hat{l}+$ は $\hat{l}$ を増加させたときの軌跡の変化する方向を意

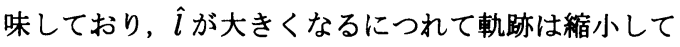
いる.

以上の結果から式 (25), (27) の指定方法に基づく制 御系は, 現実的なロープ長と見積り誤差の範囲に対し てロバスト性能を有していると結論できる．また，実 


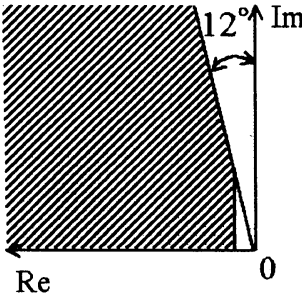

(a) Desired region

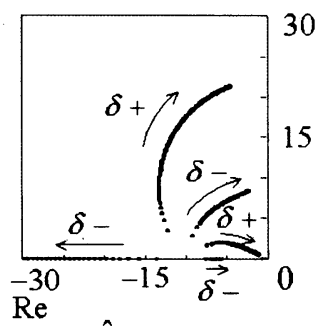

(b) $\hat{l}=0.1[\mathrm{~m}]$

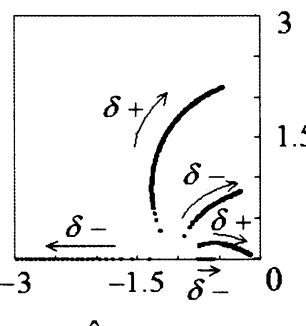

(c) $\hat{l}=10.1[\mathrm{~m}]$

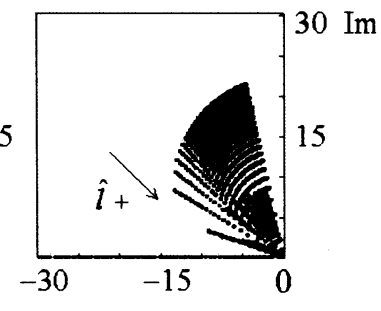

(d) $\hat{l}=0.1 \sim 10.1[\mathrm{~m}]$

Fig. 3 Poles of the proposed control system (without integrator)

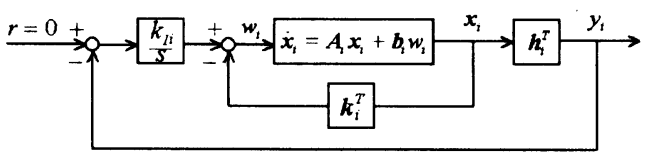

Fig. 4 Block diagram of control system

際のロープ長が公称値よりも小さくなる場合にはロバ スト性能を有する見積り誤差の領域が大きくなる。し たがって実際の設計においてはロープ長の公称值を大 きくしておくことがのぞましい.

3.4 㮴分器の曾入実際の装置では静止摩擦, クーロン摩擦の影響が大きいため, $\theta_{3}, \theta_{4}$ の位置決め 誤差が無視できない可能性がある，本節では，位置決 め誤差を低减するために，前節で述べたロバスト制御 系に積分器を挿入する方法について述べる.

図 4 のような $\theta_{3}, \theta_{4}$ の目標位置からの偏差を出力 とし、積分器を有する制御系を考える. 図4 において は, 制御対象の出力方程式を,

$$
y_{i}=\boldsymbol{h}_{i}^{T} \boldsymbol{x}_{i}, \boldsymbol{h}_{i}=\left[\begin{array}{llll}
0 & 1 & 0 & 0
\end{array}\right]^{T}
$$

としている. 内部ループの状態フィードバックゲイン $\boldsymbol{k}_{i}$ は前節と同様にループの特性多項式が式 (17) とな るように決定されるものとする. 以下では積分ゲイン $k_{I i}$ の決定方法について述べる. 図 4 の制御系の特性 多項式 $Q(s)$ はつぎのように表される. 式(12)におけ る $i=1,2$ の両制御対象に対してつぎの同じ形の特性 多項式が得られる。

$$
\begin{array}{r}
Q(s)=s^{5}+b_{4} s^{4}+b_{3} s^{3}+b_{2} s^{2}+b_{1} s+b_{0}, \\
b_{0}=\xi k_{I i}, b_{1}=c_{2} c_{4} \frac{\xi}{\hat{\xi}} \\
b_{2}=\left(c_{1} c_{4}+c_{2} c_{3}\right) \frac{\xi}{\hat{\xi}}+k_{I i} \\
b_{3}=\left(c_{1} c_{3}+c_{2}+c_{4}\right) \frac{\xi}{\hat{\xi}}+c_{2} c_{4} \frac{1}{\hat{\xi}}\left(1-\frac{\xi}{\hat{\xi}}\right), \\
b_{4}=\left(c_{1}+c_{3}\right) \frac{\xi}{\hat{\xi}}+\left(c_{1} c_{4}+c_{2} c_{3}\right) \frac{1}{\hat{\xi}}\left(1-\frac{\xi}{\hat{\xi}}\right) .
\end{array}
$$

Lienard とChipart の安定判別法 ${ }^{(12)}$ によれば, 式 (30) が安定となるための必要十分条件はつぎのとおりで ある。

$$
\begin{aligned}
& b_{i}>0, i=0, \ldots, 4, \\
& b_{3} b_{4}-b_{2}>0, \\
& 2 b_{0} b_{1} b_{4}+b_{0} b_{2} b_{3}+b_{1} b_{2} b_{3} b_{4}-b_{0}^{2} \\
& \quad-b_{0} b_{3}^{2} b_{4}-b_{1} b_{2}^{2}-b_{1}^{2} b_{4}^{2}>0 .
\end{aligned}
$$

まず，式 (33) を満足させる方法について検討する. 前節と同様にロープー吊り荷系の固有振動数の公称值 を用いて式 (25), (27) のように内部ループ系の望まし い特性多項式の係数を決定する. さらにロープ長の見 積り誤差を式 (28)により定義すると, 式 (33) をつぎ のように変形することができる

$k_{I i}^{2}-5 k_{I i} \sqrt{\hat{\xi}} \hat{\xi}+16 \hat{\xi}^{3}(1+\delta)-20 k_{I i} \sqrt{\hat{\xi}} \hat{\xi}(1+\delta)>0$.

本研究では式 (34) を簡単化するために,

$$
k_{I i}=\beta \sqrt{\hat{\xi}} \hat{\xi}
$$

と設定することを提案する. ただし $\beta$ は適当な正の定 数である. 式 (35)により, 式 (34) は,

$$
\beta^{2}+16(1+\delta)-\beta(25+20 \delta)>0
$$

となる. 式 (36) を満たすための十分条件として，そ の左辺第 1 項を無視して変形した

$$
\beta<\frac{16(1+\delta)}{25+20 \delta}
$$

が考えられる. 式 (37) では $\delta$ の範囲に応じて許容さ れる $\beta$ が異なる. 式 (37) の右辺は $\delta(>-1)$ に関して 単調増加であるが, $\delta \rightarrow \infty$ としたとき式(37) の右辺 は 0.8 となるので, $\beta$ の值は 0.8 を超えないことがわ かる. 例えば

$$
\begin{aligned}
& \beta<0.133 \text { for } \delta \geq-0.95 \\
& \beta<0.533 \text { for } \delta \geq-0.5 \\
& \beta<0.64 \text { for } \delta \geq 0.0
\end{aligned}
$$




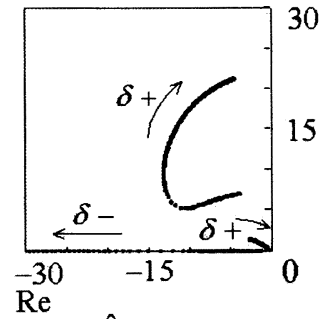

(a) $\hat{l}=0.1[\mathrm{~m}]$

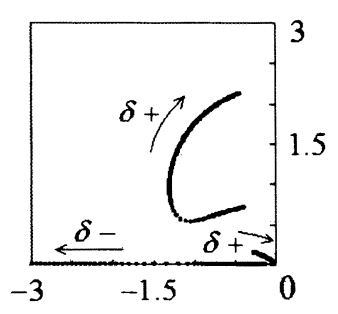

(b) $\hat{l}=10.1[\mathrm{~m}]$

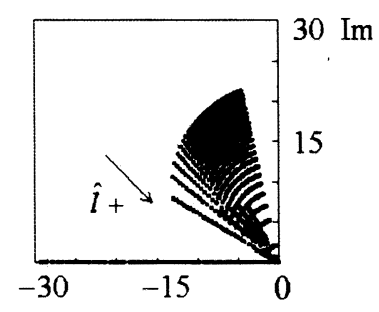

(c) $\hat{l}=0.1 \sim 10.1[\mathrm{~m}]$

Fig. 5 Poles of the proposed control system

などとなる.

式 (25),(27),(35),(37) より式 (31),(32) が満たされ ることが容易にわかる．よって本節で提案した積分ゲ インの決定方法は，ある範囲のロープ長見積り誤差に 対して制御系のロバスト安定性を保証する.

\section{5 栍分器を有する制御系のロバスト制御性能} 前節で述べた方法により制御系のロバスト安定性は 補償されるが，制御性能を犠牲にしている可能性があ る．本節では 3.3 節と同様に根軌跡を描くことにより ロバスト性能の検討を行なう.

図 5(a) は積分ゲインのパラメータを式 (38) が満た されるように $\beta=0.1$, ロープ長の公称值を $\hat{l}=0.1[\mathrm{~m}]$ とし, 式 (28) の推定誤差 $\delta$ を $-0.5 \sim 11.1$ まで変化さ せたときの極 (式 (30) の特性多項式の零点) の位置を 示している. 図中の $\delta+, \delta-$ 意味は図 3 と同様であ る. この場合には積分器のないときに比べ極が図 3(a) の斜線部分に存在する $\delta$ の範囲が狭まり, $\delta=-0.6$ の ときに図 3(a) の斜線部分の外側に極が存在した. 積 分器の無いときと同様, $l$ が $\hat{\imath}$ よりも大きいときロバ スト性能を有する $\delta$ の範囲は小さいので, 制御系設計 時には $\hat{l}$ をきくしておくことがのぞましい.

図 5(b) は $\delta$ の範囲を変えずに $\hat{l}=10.1[\mathrm{~m}]$ とした結 果である. 図5(a)を縮小した軌跡が得られている. 図 $3(a)$ の斜線部分に極が存在する $\delta$ の範囲は図 5(a) の 場合と同じであった.

図 5(c) は $\delta$ の範囲を変えずに $\hat{l} を-0.5 \sim 10.1$ の範 囲で 0.48 ずつ変化させた場合の結果である. 全ての 極は図 5(a) の斜線部分に存在し, 現実的なロープ長 と推定誤差の範囲で本方法はロバスト性能を有してい ると結論できる. 図中の $\hat{l}+$ の意味は図 3(d) のものと 同じであり, $\hat{l}$ が大きくなるにつれて軌跡は縮小する.

\section{4. 実 酫 結 果}

4.1 実験装置図 6 に示すような実験装置を用 いて提案法の有効性を検証した.ブームおよびその 土台は電流フィードバックが施された减速器付の DC
モータによって駆動される. 二つのモータは同一のも のを使用した. 表 1 に実験装置の諸元を示す. 表中記 号の意味はつぎのとおりである. $J_{m}$ : モータの慣性 モーメント, $K_{m}$ : モータのトルク定数と電流フィー ドバック回路の電圧電流変換係数の積, $N$ :モー夕减速 器の減速比, $J_{1}:$ モータ 1 の回転軸まわりのブームの 慣性モーメント， $J_{2}:$ モータ 2 の回転軸まわりのブー ム土台の慣性モーメント.

図 2 の外乱オブザーバに用いる慣性公称值には以下 の值を用いた。

$$
J_{i+2}=J_{i}+\frac{J_{m}}{N^{2}}, i=1,2 .
$$

またトルク $\tau_{i}$ と計算機からの指令電圧 $v_{i}$ の関係は以 下の式で表される.

$$
\tau_{i}=\frac{K_{m}}{N} v_{i}, i=1,2 .
$$

角度 $\theta_{3}, \theta_{4}$ はモー夕に取り付けられたエンコーダに よって計測される. 角度の計測分解能は $1.8 \times 10^{-3}\left[{ }^{\circ}\right]$ である。

角度 $\theta_{1}, \theta_{2}$ は図 7 に示す計測器により測定した. 図 7 においてポテンショメータ 1 はブームに固定されて いる. ポテンショメータ 2 は部品 1 に固定されており, ポテンショメータ 1 の回転軸まわりに回転する. 部品 2 はロッドと共にポテンショメータ 2 の回転軸まわり に回転する. 部品 3 はロッドに対して, 部品 4 は部品 3 に対してそれぞれ回転する．また部品 4 は貫通穴を 介してロープに沿ってガタなく滑らかにスライドする. なお, 計測器の部品はすべてアルミ製とし, 荷振れが 無い状態においてブームとロッドの中心軸が同一鉛直 面内に存在するように設置した，角度の計測分解能は $6.4 \times 10^{-2}\left[^{\circ}\right]$ である. ポテンショメータ 1,2 より出 カされる電圧值をそれぞれ $\theta_{1}, \theta_{2}$ に換算している.

\section{2 制御結果 まず図 2 の外乱オブザーバの効}

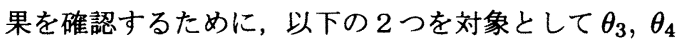
に関する制御性能の比較を行なった。 


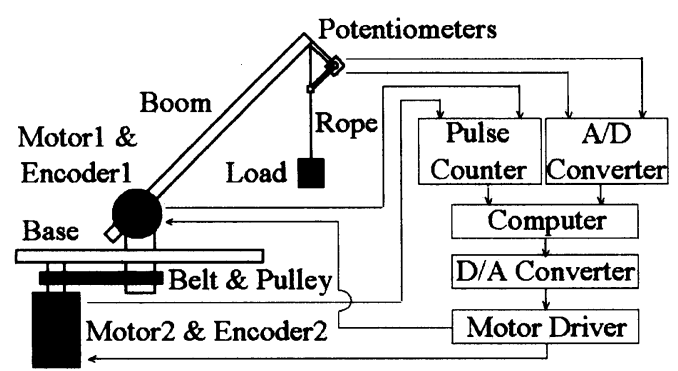

Fig. 6 Experimental system

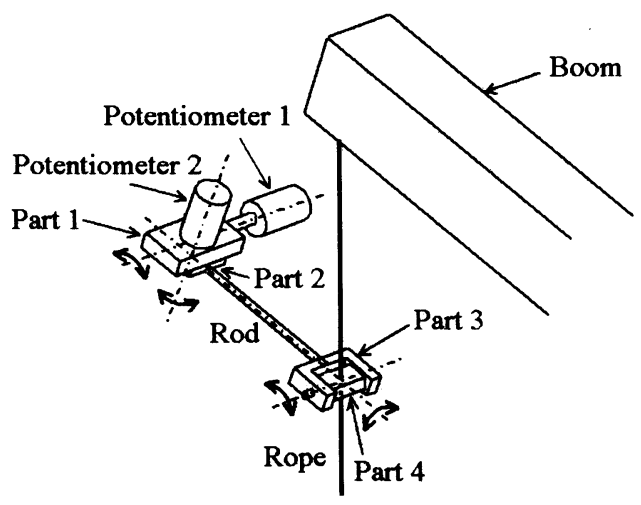

Fig. 7 Sensor system for measuring load sway

Table 1 Parameter values of the robot

\begin{tabular}{c|l||c|l}
\hline$J_{m}$ & $2.08 \times 10^{-4}\left[\mathrm{kgm}^{2}\right]$ & $N$ & 0.02 \\
$K_{m}$ & $3.72 \times 10^{-2}[\mathrm{Nm} / \mathrm{V}]$ & $l_{b}$ & $0.65[\mathrm{~m}]$ \\
$J_{1}$ & $0.13\left[\mathrm{kgm}^{2}\right]$ & $J_{2}$ & $0.23\left[\mathrm{kgm}^{2}\right]$ \\
\hline
\end{tabular}

(d1) 外乱オブザーバを用いて近似的に式 (2) とした もの.

(d2) 図 1 のロープ張力 $f$ のブームに対する影響を 無視して, 慣性, 遠心力, コリオリカ, 重力の影 響を逆動力学法（トルク計算法） ${ }^{(11)}$ により補償 したもの.

上の 2 つ対象に以下の P D制御を応用する.

$$
\begin{aligned}
u_{i}= & k_{p i} e_{i+2}+k_{v i} \dot{e}_{i+2}, \\
& e_{i+2}=r_{i+2}-\theta_{i+2}, i=1,2 .
\end{aligned}
$$

ただし $k_{p i}, k_{v i}$ はそれぞれ $u_{i}$ を生成するためのゲ インであり, $r_{i+2}$ は $\theta_{i+2}$ の目標值である. ゲインは $k_{p i}=50\left[1 / \mathrm{sec}^{2}\right], k_{v i}=10[1 / \mathrm{sec}](i=1,2)$ とした. 目標軌道には始点と終点において速度, 加速度が 0 と なるつぎのサイクロイド曲線を用いた。

$$
r_{i}=\left(\theta_{i f}-\theta_{i 0}\right)\left[\frac{t}{t_{f}}-\frac{1}{2 \pi} \sin \left(2 \pi \frac{t}{t_{f}}\right)\right]+\theta_{i 0},
$$

ただし $\theta_{i 0}$ は $\theta_{i}$ の初期值, $t, t_{f}$ はそれぞれ現在時刻, $\theta_{i}$ が最終目標位置に到達するまでに要する時間であ る. ロープ長を $l=0.5[\mathrm{~m}]$ とし, 吊り荷の質量を $m=0.1,1.0,5.0[\mathrm{~kg}]$ と変化させてシミュレーショ ンを行なった. また装置の都合上 $m=0.1[\mathrm{~kg}]$ のとき のみ実験を行なった. 角度 $\theta_{3}, \theta_{4}$ はロータリエンコー ダによって計測した. 角速度は角度の時間差分值を 1 次のローパスフィルタに通過させたものを利用した. フィルタのカットオフ周波数は図 2 の外乱オブザーバ のものとともに $10[\mathrm{~Hz}]$ である. サンプリング時間は 10 [msec] とした. 結果を図 8 に示す. 図 8(a) は外乱 オブザーバを用いたもの，(b) はそうでないものであ る. 図 8(a)(b) いずれの場合も， $m=0.1[\mathrm{~kg}]$ のとき のシミュレーション結果と実験結果はほぼ一致してい る. 図 8(b) において追従誤差が大きいのは摩擦の影 響による. 吊り荷の質量の変化に対して図 8(a) は口 バスト性を有しているが, 図 8(b) は特に起伏動作の 性能劣化が顕著である．以上から外乱オブザーバの効 果が確認された．つぎに吊り荷の残留振動抑制に関す る実験について述べる．上述の実験の途中で以下の条 件を満たしたとき，本論文で提案する振動制御を開始 するものとした。

$$
\left|r_{i f}-\theta_{i}\right|<1^{\circ}, i=3,4 .
$$

図 9 に振動制御と積分器の効果を検証した実験結果を 示す. 図 9 と図 10 において図中に示す点線は目標值, 実線は実測值を表す。

図 9(a) は吊り荷の振動抑制を行なわず式 (43) のみ によって制御を行なった結果である．吊り荷の残留振 動が顕著であることが知れる。

図 9(b) は式 (43) による搬送の後, 積分器を含まず に式 (25)(27) の指定方法のみによって制振と位置決め 制御を行なった結果である.ロープ長は制御系設計に 用いた值，実際の值ともに $\hat{l}=l=0.5[\mathrm{~m}]$ とした. 制 御系の極は $-4.429[1 / \mathrm{sec}]$ の重極となる. 吊り荷の振 動は抑制されているが, $\theta_{3}, \theta_{4}$ の位置決め誤差が確認 できる.

図 9(c) は設計に用いたロープ長の值, 実際の值と もに $\hat{l}=l=0.5[\mathrm{~m}]$ とし積分器を挿入した結果で ある. 式 (35) の $\beta$ の值は 3.5 節でロバスト性能を 検討した $\beta=0.1$ とした. 制御系の極は $-4.706 \pm$ $j 2.368,-0.813 \pm j 0.508,-6.676[1 / \mathrm{sec}]$ となる.ただ し $j$ は虚数単位である. 角度 $\theta_{3}$ の位置決め誤差が低 减していることがわかる，以上より，振動制御と積分 器の効果が確認された.

比較の対象として，ロープ長が $l=0.5[\mathrm{~m}]$ のときに 制御系の特性多項式がつぎの式となるように，図 4 の 


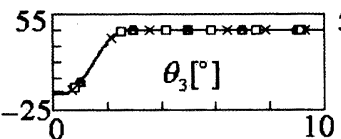

(a) With disturbance observer $[-.-$ reference $\rightarrow-$ simulation

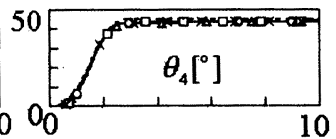

Time[sec]

(b) Without disturbance observer $\left.\rightarrow \begin{array}{c}\text { experiment } \\ m=0.1[\mathrm{~kg}]\end{array}-\square_{m=1.0[\mathrm{~kg}]}^{\text {simulation }} \rightarrow{ }_{m=5.0[\mathrm{~kg}]}^{\text {simulation }}\right]$

Fig. 8 Verification of the effectiveness of disturbance observer
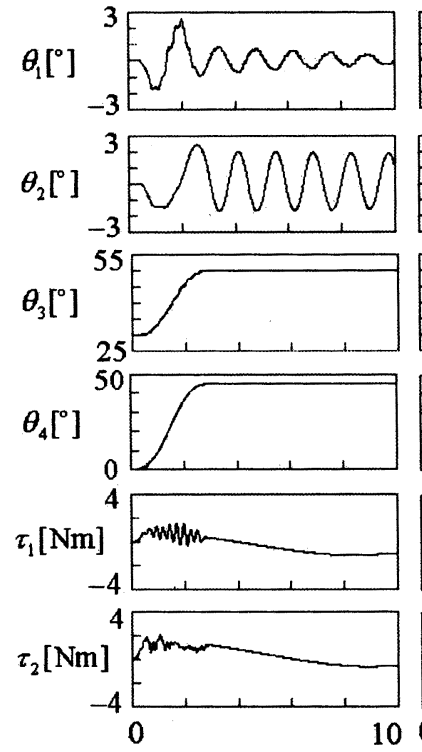

(a) Without vibration control
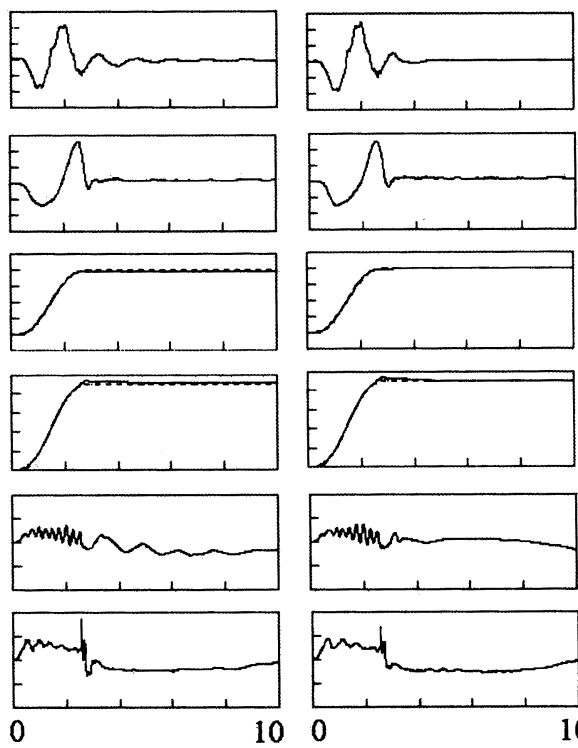

(b) Without integrator (c) With integrator
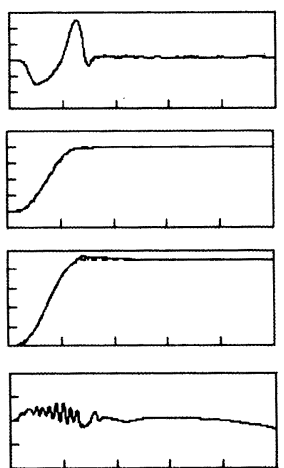
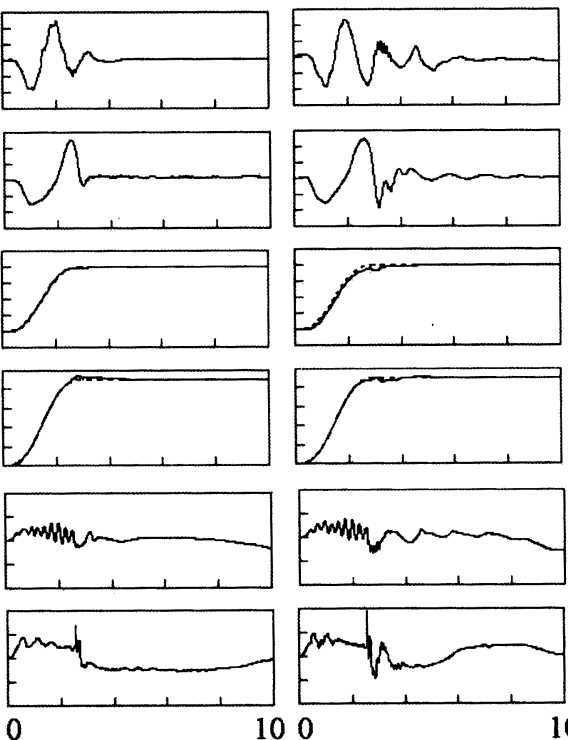

100
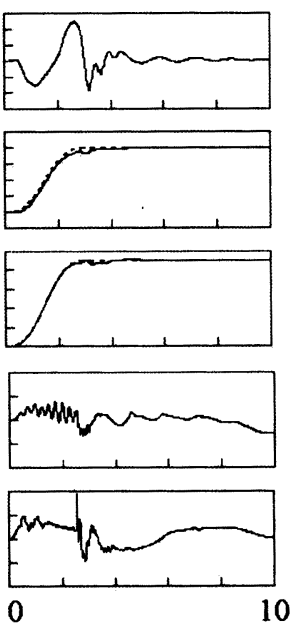

Time[sec]

(d) Conventional

Fig. 9 Experimental results : Verification of the effectiveness of vibration control and integrator

フィードバックゲイン $\boldsymbol{k}_{i}$ と積分ゲイン $k_{I i}$ を指定し て実験を行なった結果を図 9(d) に示す.

$$
Q_{d}(s)=(s+p+j p)(s+p-j p)(s+6 p)^{3} .
$$

ただし $p$ は適当な正の定数である.これにより制御系 は 2 つの最適堿衰係数を持つ代表極 $-p \pm j p$ とその実 部の 6 倍の大きさを持つ 3 つの実極 $-6 p$ を有する.こ の方法は高次系の応答を望ましい2 次系の応答に近似 させる通常の方法である. 図 9(d) は実際のロープ長 の値を設計值と同じ $l=0.5[\mathrm{~m}]$ とし, $p=1.3[1 / \mathrm{sec}]$ とした結果である.この場合はロープ長見積り誤差が 存在しないため, 図 9(c) と同様に良好な制御性能が 得られている.

なお本方法における制御入力の大きさは，制御系の 代表極として最適减衰係数を与えた従来の方法に比較 して大きく変わらないことが実験結果より確認できる.
図 10 は本方法のロープ長に関するロバスト性の検 証を行った実験結果である. 図9(c)の実験において設 計された制御器を, 実際のロープ長が $l=0.25[\mathrm{~m}]$ の場 合に応用した結果を図 10(a) に示す．実際の制御系の 極は $-4.839 \pm j 7.384,-0.554 \pm j 0.371,-1.740[1 / \mathrm{sec}]$ となる. 吊り荷の残留振動, ブームの位置決め誤差共 に低减されており，良好な制御性能が得られている. 図 10(b) は実際のロープ長を $l=0.75[\mathrm{~m}]$ とした結果で ある. 実際の制御系の極は $-2.379 \pm j 3.037,-1.029 \pm$ $j 0.594,-14.875[1 / \mathrm{sec}]$ となる. 図 10(a) と同様に良 好な制御結果が得られている.

図 10(c) は式 (45) を用いて設計した図 9(d) と同じ 制御系ゲインを用い，実際のロープ長を $l=0.25[\mathrm{~m}]$ とした場合の結果である.なお根軌跡を描くことによ り $l<0.258[\mathrm{~m}]$ のとき制御系が不安定になることを理 論的に確認している：実禹を行なった結果, 図のよう に制御系が不安定となった．同じ制御系グインを用い 


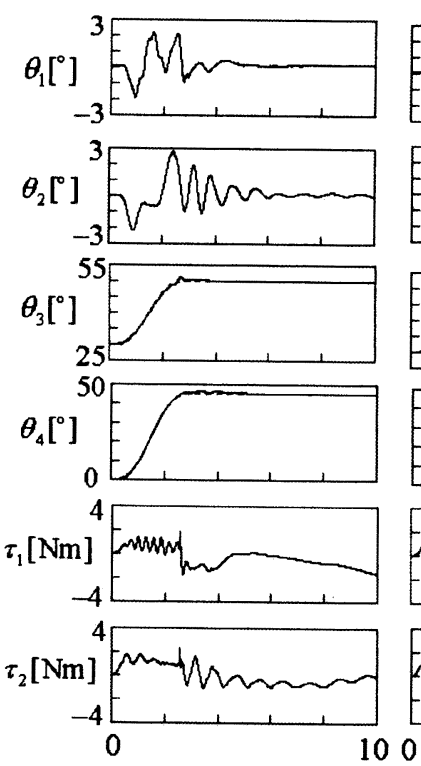

(a) Proposed $(l=0.25[\mathrm{~m}])$
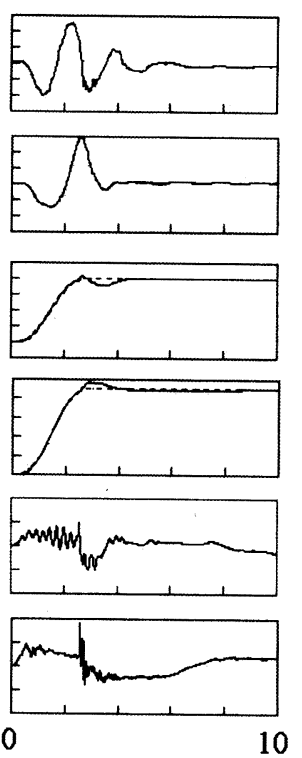

(b) Proposed

$(l=0.75[\mathrm{~m}])$
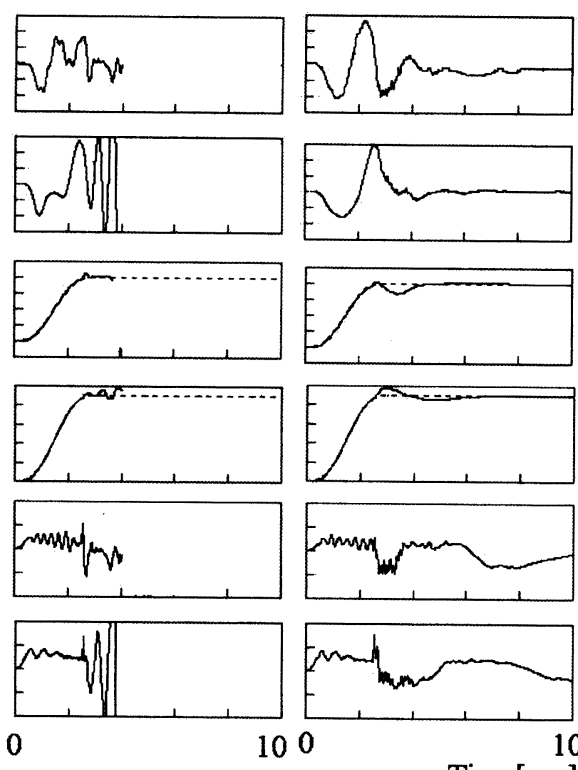

(c) Conventional $(l=0.25[\mathrm{~m}])$
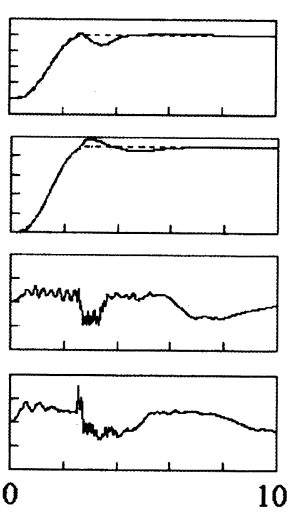

Time[sec]

(d) Conventional $(l=0.75[\mathrm{~m}])$

Fig. 10 Experimental results : Verification of robust stability

$l=0.75[\mathrm{~m}]$ とした場合の結果を図 $10(\mathrm{~d})$ に示す. 実験 結果は図 10(b) と同程度の性能が得られている.

なお図 10 の (b) と (d) の制御入力について, 本方法 を用いた場合のその大きさは, 従来の方法と比較して 大きく変わらないことが確認できる.

以上の結果から本研究で提案する方法は, 式 (45) による一般的な特性多項式の指定方法に比較してロバ スト性能を有する範囲が広く, 実用上有効であるとい える.

\section{5. 結}

本論文では旋回クレーンの残留振動を抑制する一ロ バスト制御法を提案し，その妥当性を実験により検証 した. 結果を要約すれば以下のようである.

1) ロープ長に関するロバスト安定性が保証される.

2）現実的な範囲のロープ長見積り誤差に対してロバ スト性能を有する。

3）制御系設計に複雑な繰り返し計算を必要とせず, 設計が容易である.

4) 制御則のアルゴリズムがロバスト制御の一つであ る適応制御と比較して简単である.

5）荷振れ角速度情報を必要としない.

6) 吊り荷の質量, 関節駆動部の摩擦等に関しても口
バスト性を有する.

なお，本研究の結果はトロリが並進運動するタイプ のクレーンにも応用可能と考える.

\section{文献}

（1）土屋，伊藤，計測と制御，13-10，(1974)，797.

（2）坂和, 中住, 計測自動制御学会論文集, 21-3，(1985), 298.

（3）大音，安信，計測自動制御学会論文集，33-9，(1997), 923.

(4) 日野ほか, 嘰論, 65-632, C(1999), 1426.

(5) 多田ほか, 機論, 65-634, C(1999), 2352.

(6) 高木, 西村, 機論, 65-640, C(1999), 4692.

(7) 近藤ほか, 㙨論, 68-665, C(2002), 68.

(8) 川崎ほか, 機論, 68-676, C(2002), 3597.

(9) 矢野ほか, 㙨論, 68-676, C(2002), 3603.

(10) 大西, 日本ロボット学会誌, 11-4, (1993), 486.

(11) J.J.Craig, (三浦, 下山訳)，ロボティクス, 共立出版, (1991), 275

（12）高木，メカトロニクスのための制御工学， (1993)，115, コロナ社.

(13) 文献 (12) の 156. 